\title{
Karakterisasi Mutu Fisik Bulir 30 Genotipe Padi Generasi F5 Hasil Seleksi dari Persilangan Sintanur X PTB33 dan Pandanwangi X PTB33
}

\author{
Nono Carsono ${ }^{1 *}$, Nita Fitria ${ }^{2}$, Santika Sari ${ }^{1}$, dan Dedi Ruswandi ${ }^{1}$ \\ ${ }^{1}$ Program Studi Agroteknologi dan Laboratorium Pemuliaan Tanaman, Fakultas Pertanian, \\ Universitas Padjadjaran, Jl. Raya Bandung-Sumedang KM 21 Jatinangor, Jawa Barat 45363 Indonesia \\ ${ }^{2}$ Program Studi Agroteknologi, Fakultas Pertanian, Universitas Padjadjaran, Jl. Raya Bandung- \\ Sumedang KM 21 Jatinangor, Jawa Barat 45363 Indonesia \\ *Alamat korespondensi: n.carsono@unpad.ac.id
}

\section{ABSTRACT \\ Characterization of physical grain quality traits of 30 rice genotypes of selected $F_{5}$ progenies derived fromhybridization of Sintanur X PTB33 and Pandanwangi X PTB33}

Rice genetic improvement is not only focus on improving the productivity, but also increasing rice grain quality traits which are preferred by consumers, such as, size, shape, and appearance of the grain. In order to develop the high grain quality traits, some hybridizations of valuable parents i.e. cv. Sintanur, Pandanwangi and PTB33 have been made. These selected progenies have reached F5 generation, but the physical grain quality testing is not performed yet before these promising lines will be released. This experiment aimed to obtain the promising rice genotypes with best physical grain quality traits. The experiment was arranged in a completely randomized design (CRD), consisted of 34 genotypes as treatment (including four check varieties) and replicated three times. Performance of each genotype was done by comparing with the check varieties by Least Significant Increase (LSI). LSI test showed that all genotypes derived from hybridization of Pandanwangi X PTB33 (PP) and SP8725-29 had better physical grain quality traits than those of their parents. All selected genotypes will be utilized for adaptability and stability testing in the future.

Keywords: Least Significant Increase (LSI), Grain size, Grain shape, Rice,

\begin{abstract}
ABSTRAK
Perbaikan genetik padi saat ini tidak hanya mengarah pada peningkatan produktivitas saja, namun juga ke arah perbaikan mutu terutama karakter mutu beras yang disukai konsumen, seperti, ukuran, bentuk, dan penampilan butir beras. Dalam rangka mengembangkan karakter mutu fisik yang baik, telah dilakukan beberapa persilangan dari tetua-tetua yang terpilih, seperti Sintanur, Pandanwangi, dan PTB33. Hasil persilangan tersebut telah mencapai generasi $\mathrm{F}_{5}$, akan tetapi pengujian mutu fisik bulir belum dilakukan, sebelum galur-galur harapan tersebut dilepas. Penelitian ini bertujuan untuk memperoleh genotipe padi unggul yang memiliki karakter mutu fisik bulir terbaik. Penelitian ini menggunakan Rancangan Acak Lengkap (RAL), terdiri dari 34 genotipe (termasuk 4 varietas cek) dan dilakukan sebanyak 3 ulangan. Penampilan genotipe-genotipe padi yang diuji dibandingkan dengan varietas ceknya dievaluasi dengan menggunakan Least Significant Increase (LSI). Berdasarkan uji LSI, seluruh genotipe hasil persilangan varietas Pandanwangi X PTB33 (PP) dan SP87-25-29 memiliki mutu fisik bulir yang lebih baik dibandingkan tetuanya. Genotipe-genotipe yang telah terseleksi akan dilanjutkan guna pengujian adaptabilitas dan stabilitas.
\end{abstract}

Kata kunci: Bentuk bulir, Ukuran bulir, Least Significant Increase (LSI), Padi

PENDAHULUAN

Pemuliaan padi saat ini tidak hanya mengarah pada peningkatan produktivitas saja, namun juga pada ketahanan terhadap hama dan penyakit utama, serta memiliki karakter mutu beras yang disukai konsumen (Syahri \& Somantri, 2016). Salah satu mutu beras yang penting dalam pemuliaan 
yaitu mutu fisiknya. Mutu fisik bulir setiap varietas padi berbeda-beda. Perbedaan mutu fisik bulir tersebut dapat disebabkan oleh adanya proses diversifikasi dengan berbagai adaptasi yang menyebabkan terjadinya evolusi (Bhattacharya, 2005). Selain itu, mutu fisik bulir yang dihasilkan dari padi pada dasarnya dipengaruhi oleh genotipe, lingkungan (iklim dan tanah), dan manajemen budidaya (Slafer, 1994; Richards, 2000). Perbedaan mutu fisik bulir padi dapat dilihat dari segi ukuran, bentuk, warna, penampilan, serta kebersihan beras yang akan mempengaruhi harga beras di pasar (Toquero, 1991).

Preferensi konsumen berbeda-beda terhadap penampilan beras yang diinginkan. Butir beras yang panjang dan ramping umumnya disukai oleh konsumen di Cina Selatan, AS, dan negaranegara di Asia Tenggara dan Selatan, sedangkan konsumen di Jepang, Korea, dan Cina Utara lebih memilih butir beras yang pendek dan bundar (Unnevehr et al., 1992; Juliano \& Villareal, 1993). Oleh karena itu, mutu fisik beras tidak boleh diabaikan karena berhubungan dengan preferensi konsumen, permintaan pasar, serta harga.

Perakitan varietas padi tipe baru telah banyak dilakukan. Salah satu metode yang dapat dilakukan yaitu dengan metode persilangan antara varietas Sintanur X PTB33 dan Pandanwangi X PTB33. Pemilihan tetua-tetua tersebut didasarkan atas keunggulan dan tujuan persilangan yang ingin dicapai. Hasil persilangan-persilangan tersebut saat ini telah mencapai generasi $\mathrm{F} 5$, sehingga pengujian mutu fisik bulir sudah bisa dan memenuhi syarat untuk dilakukan sebelum galur-galur tersebut dilepas.

Pengujian mutu fisik merupakan salah satu bagian dari pengembangan varietas tanaman unggul baru. Pengujian mutu fisik padi umumnya dapat menggunakan uji Least Significant Difference (LSD)/BNT. Penelitian Lestari dkk. (2011), Hairmansis dkk. (2013), dan Girma et al. (2016) menggunakan uji LSD untuk menentukan genotipegenotipe yang memiliki karakter mutu yang sama dengan varietas pembandingnya. Akan tetapi, uji tersebut tidak dapat mengestimasi genotipe-genotipe yang memiliki karakter-karakter mutu fisik yang lebih baik daripada varietas pembandingnya. Oleh karena itu, pada penelitian ini akan dilakukan pengujian menggunakan uji Least Significant Increase (LSI), karena menurut Petersen (1994), uji LSI banyak digunakan untuk menentukan genotipe yang berpenampilan lebih baik dari pembandingnya. Tujuan dari penelitian ini adalah untuk mendapatkan genotipe padi unggul yang memiliki karakter mutu fisik bulir terbaik, seperti warna gabah dan kulit ari yang terang, ukuran dan bentuk gabah yang ramping, persen pengapurannya yang kecil, serta memiliki persen kebeningan yang tinggi.

\section{BAHAN DAN METODE}

Penelitian dilakukan di Laboratorium Pemuliaan Tanaman Universitas Padjadjaran pada bulan Desember 2019 hingga Februari 2020. Percobaan menggunakan Rancangan Acak Lengkap (RAL) dengan faktor tunggal yaitu genotipe dan dilakukan pengulangan sebanyak 3 kali ulangan. Dalam satu percobaan digunakan 30 bulir padi yang diambil secara acak. Pengambilan bulir per genotipe dilakukan pada malai dalam satu tanaman yang sama.

Materi genetik yang digunakan adalah bulir padi dari 30 genotipe padi generasi $F_{5}$ hasil persilangan Sintanur X PTB33 (SP) dan Pandanwangi X PTB33 (PP) dan 4 varietas pembandingnya yaitu varietas Sintanur, PTB33, Ciherang, dan Pandanwangi. Karakter-karakter yang diamati yaitu warna gabah (WG), panjang gabah (P), lebar gabah (L), rasio P/L (PL Ratio), bobot 100 butir (B), tipe pengapuran (TP), butir mengapur (BM), pengapuran $(\mathrm{PK})$, kebeningan $(\mathrm{K})$, dan warna kulit ari beras (WKA). Karakter-karakter tersebut diamati berdasarkan acuan dari Standard Evaluation System for Rice (SES) (IRRI, 2002). Data dianalisis menggunakan perangkat lunak microsoft excel.

Untuk menentukan genotipe yang memiliki karakter panjang gabah $(\mathrm{P})$, lebar gabah $(\mathrm{L})$, rasio $\mathrm{P} / \mathrm{L}$ (PL Ratio), bobot 100 butir (B), pengapuran (PK), dan kebeningan $(\mathrm{K})$ yang lebih baik dari pembandingnya, maka digunakan uji Least Significant Increase (LSI) dengan rumus menurut Petersen (1994), yaitu:

$$
\mathrm{LSI}=\mathrm{t} \_\alpha \sqrt{ }(2 \mathrm{MSE} / \mathrm{r}) .
$$

Keterangan :

$t \_\alpha=$ nilai $t$-tabel untuk eka arah

$\mathrm{r}=$ banyaknya ulangan

MSE $=$ varians error dari tabel Anova

- Apabila $|x i| \geq x i^{\prime}+$ LSI0,05, maka hasil pengujian berbeda nyata, nilai genotipe uji lebih baik dari varietas pembandingnya

- Apabila $|x i|<x i^{\prime}+$ LSI0,05, maka hasil pengujian tidak berbeda nyata, nilai genotipe uji tidak lebih baik dari varietas pembandingnya.

- Apabila $|x i|<x i '$ - LSI0,05, maka hasil pengujian berbeda nyata, nilai genotipe uji lebih baik dari varietas pembandingnya. 
- Apabila $|x i| \geq x i^{\prime}$ - LSI0,05, maka hasil pengujian tidak berbeda nyata, nilai genotipe uji tidak lebih baik dari varietas pembandingnya.

\section{HASIL DAN PEMBAHASAN}

Berdasarkan pengamatan yang dilakukan, dapat diketahui bahwa warna gabah termasuk dalam kategori Greyed-Orange Group (164 A dan B) dan Greyed-Yellow Group (161 A). Pada karakter warna gabah tidak memiliki banyak perbedaan di antara genotipe-genotipe yang diamati. Warna gabah yang merupakan kategori Greyed-Orange Group 164 B merupakan warna yang mendominasi yaitu terdapat pada 23 genotipe dan varietas pembandingnya (SP874-8, SP87-4-13, SP87-4-21, SP87-4-24, SP87-4-26,
SP87-4-30, SP87-7-20, SP87-7-23, SP87-7-27, SP877-28, SP87-25-1, SP87-25-3, SP87-25-5, SP87-25-14, SP87-25-23, SP87-25-29, SP87-32-3, SP87-32-5, SP87-32-12, SP87-32-14, SP87-32-29, SP87-32-30, dan PTB33). Warna gabah dengan kategori GreyedYellow Group 161 A terdapat pada 9 genotipe dan varietas pembanding ( $\mathrm{PP} 48-5-1, \mathrm{PP} 48-5-2, \mathrm{PP} 48-5-6$, PP48-5-16, PP48-5-20, PP48-5-29, Sintanur, Ciherang dan Pandanwangi). Pada kategori GreyedOrange Group 164 A hanya terdapat pada 2 genotipe saja, yaitu SP87-7-9 dan SP87-7-19. genotipe dan varietas pembanding ( $\mathrm{PP} 48-5-1$, PP48-5-2, $\mathrm{PP} 48-5-6$, PP48-5-16, PP48-5-20, PP48-5-29, Sintanur, Ciherang dan Pandanwangi). Pada kategori GreyedOrange Group 164 A hanya terdapat pada 2 genotipe saja, yaitu SP87-7-9 dan SP87-7-19.

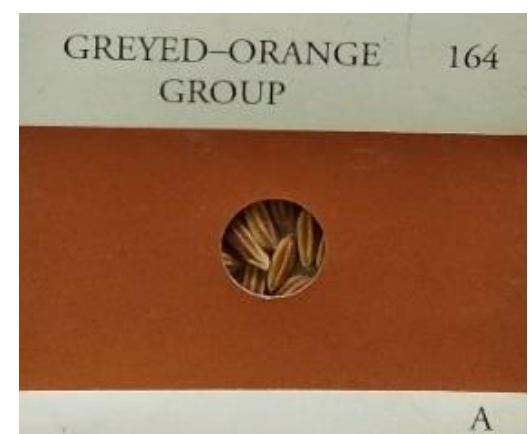

(a)

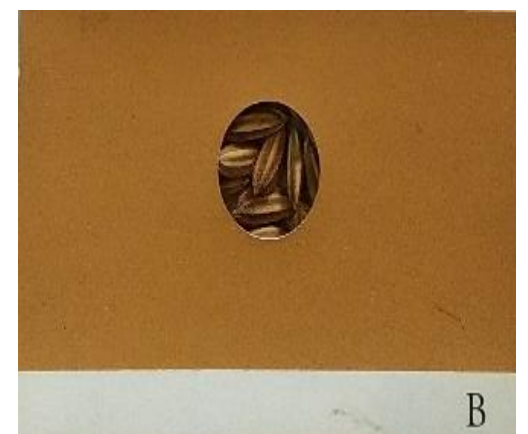

(b)

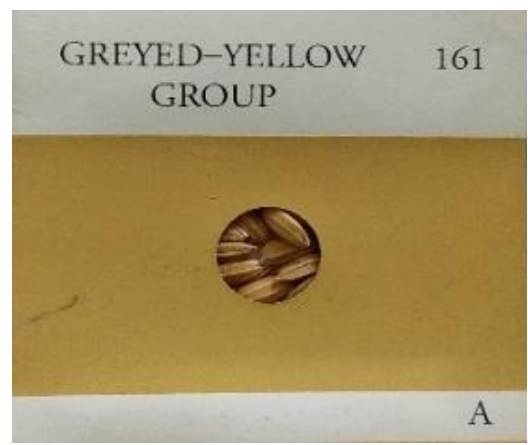

(c)

Gambar 1. Warna gabah; (a) Greyed-OrangeGroup 164 A; (b) Greyed-OrangeGroup 164 B; dan (c) Greyed-Yellow Group 161 A.

Hasil pengamatan pada karakter warna kulit ari beras menunjukkan bahwa seluruh kulit ari beras termasuk ke dalam kategori Greyed-Yellow Group 161 C, kecuali pada PTB33 yang merupakan kategori Greyed-Orange Group 175 A. PTB33 merupakan beras putih tetapi memiliki kulit ari yang berwarna merah. Hal ini diduga karena genotipe PTB33 memiliki kandungan pigmen antosianin pada kulit arinya. Pigmen antosianin yang terkandung pada tanaman akan menyebabkan warna kemerahmerahan. Menurut Chaudhary (2003), pigmen antosianin sangat berpengaruh dalam menentukan warna beras, dan terdapat pada lapisan perikarp, kulit biji (seed coat) atau aleuron/kulit ari.

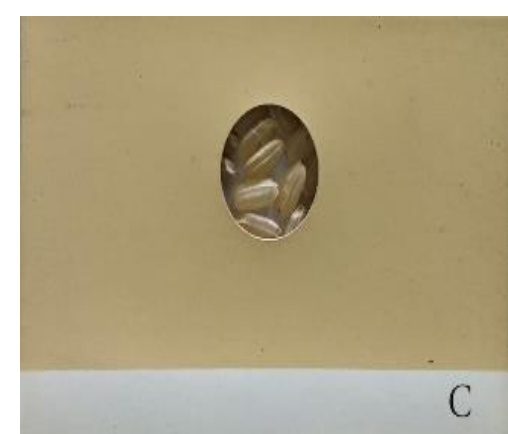

(a)

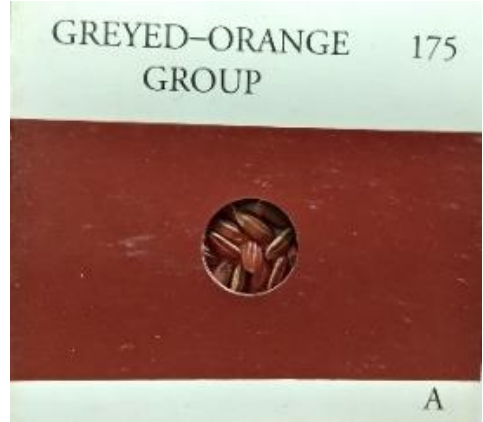

(b)

Gambar 2. Warna kulit ari beras; (a) Greyed-Yellow Group 161 C; dan (b) Greyed-Orange Group 175 A 


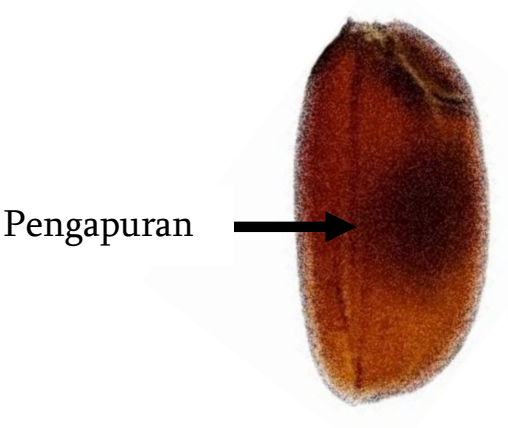

(a)

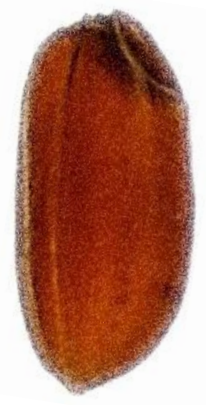

(b)

Gambar 3. Pengapuran; (a) putih pada bagian perut; dan (b) tidak ada pengapuran.

Warna kulit ari beras dipengaruhi oleh kandungan pigmen antosianin. Dwiatmini \& Afza (2018) menyatakan bahwa semakin gelap warna beras, mengindikasikan semakin tinggi kandungan antosianinnya. Antosianin adalah kelompok pigmen yang menyebabkan warna kemerah-merahan, dan letaknya berada di dalam cairan sel yang bersifat larut dalam air (Castañeda-Ovando et al., 2009).

Pada pengamatan yang telah dilakukan berdasarkan acuan dari Standard Evaluation System for Rice (SES) (IRRI, 2002), diketahui bahwa seluruh genotipe uji memiliki penampilan butiran yang baik yaitu untuk karakter tipe pengapuran dan butir mengapur. Butir mengapur hanya terdapat pada varietas pembanding saja yaitu PTB33. Genotipe PTB33 memiliki tipe pengapuran yaitu putih pada bagian perut yang dikendalikan oleh gen $q \mathrm{ACE}$, $q \mathrm{DEC}$, dan $q \mathrm{PGWC}$ (Gao et al., 2016). Selain itu, genotipe PTB33 memiliki butir mengapur (chalkiness) yang tergolong besar ( $>20 \%$ dari luas butiran). Butir mengapur yang besar pada PTB33 diduga disebabkan karena PTB33 adalah varietas lokal India, sehingga syarat tumbuhnya tidak sesuai dengan lingkungan yang berada di Jatinangor.

PTB33 adalah genotipe yang membawa banyak gen resistensi terhadap brown planthopper (BPH), dan menunjukkan resistensi spektrum luas terhadap semua populasi BPH dan sering digunakan untuk memverifikasi resistensi (Bhogadhi et al., 2015). Hal itulah yang menjadi alasan bahwa genotipe PTB33 unggul dalam segi ketahanan terhadap wereng coklat, sehingga mutu fisik bulir bukanlah sesuatu yang diharapkan pada varietas РTB33.
Pengapuran atau chalkiness merupakan salah satu karakter penting yang akan menentukan kualitas penampilan butiran beras. Pengapuran akan mempengaruhi kualitas penggilingan, karena beras yang mengalami pengapuran akan lebih rapuh dan mudah patah karena terganggunya pengisian pati seperti amilosa sehingga kepadatan butiran pati pada butir beras akan rendah dibandingkan butir yang tidak mengalami pengapuran (del Rosario et al., 1968). Meskipun demikian, menurut Thi-Lang et al. (2017) menyatakan bahwa butir mengapur atau chalkiness tidak akan mempengaruhi kualitas beras yang dimasak, karena kualitas beras yang dimasak dipengaruhi oleh kandungan amilosanya. Selain itu, chalkiness pada beras akan hilang dengan sendirinya saat dimasak.

Karakter bobot 100 butir gabah (B), panjang gabah $(\mathrm{P})$, lebar gabah $(\mathrm{L}) \mathrm{s}$ rasio $\mathrm{P} / \mathrm{L}$ gabah (PL rasio), pengapuran $(\mathrm{P})$ dan kebeningan $(\mathrm{K})$ yang telah diuji $\mathrm{F}$ dan menunjukkan nilai yang signifikan selanjutnya diuji lanjut menggunakan uji LSI. Hasil uji LSI untuk karakter-karakter tersebut dapat dilihat pada Tabel 1.

Bobot 100 butir merupakan variabel yang sangat penting dalam karakterisasi mutu fisik bulir. Hal tersebut disebabkan karena bobot 100 butir berkorelasi positif dengan bentuk gabah seperti, panjang gabah, lebar gabah, rasio panjang per lebar dan ketebalan gabah (Tan et al., 2000). Pada karakter bobot 100 butir dapat diketahui bahwa tidak ada genotipe uji yang memiliki bobot lebih baik dari seluruh varietas pembandingnya. Hampir seluruh genotipe memiliki bobot 100 butir gabah yang lebih baik dari 2 varietas pembanding (PTB33 dan Ciherang), sedangkan genotipe SP87-4-13, SP87-3230, dan PP48-5-29 hanya lebih baik dari PTB33 saja. 
Bobot 100 butir gabah pada Tabel 1 memperlihatkan bahwa karakter tersebut berada pada kisaran nilai 2,55-2,88 g. Suryanugraha dkk. (2017) menyatakan bahwa pada masing-masing genotipe yang berbeda genetiknya, maka akan berbeda pula bobot 100 butirnya.

Tabel 1. Hasil uji LSI pada nilai rata-rata karakter genotipe-genotipe padi generasi $F_{5}$

\begin{tabular}{|c|c|c|c|c|c|c|c|c|c|c|c|c|}
\hline \multirow{2}{*}{$\begin{array}{l}\text { Genotipe/Varietas Cek } \\
\text { SP87-4-8 }\end{array}$} & \multicolumn{2}{|l|}{ B } & \multicolumn{2}{|c|}{$P$} & \multicolumn{2}{|l|}{$\mathrm{L}$} & \multicolumn{2}{|c|}{ PL Rasio } & \multicolumn{2}{|l|}{ PK } & \multicolumn{2}{|l|}{$\mathrm{K}$} \\
\hline & 2,77 & $\mathrm{bc}$ & 7,77 & B & 3,07 & & 2,53 & & 6,67 & $\mathrm{~b}$ & 93,33 & $\mathrm{~b}$ \\
\hline SP87-4-13 & 2,60 & $\mathrm{~b}$ & 7,74 & B & 3,01 & ad & 2,57 & & 7,78 & $b$ & 92,22 & $\mathrm{~b}$ \\
\hline SP87-4-21 & 2,71 & bc & 7,73 & B & 2,99 & ad & 2,59 & $\mathrm{~b}$ & 6,67 & $b$ & 93,33 & $\mathrm{~b}$ \\
\hline SP87-4-24 & 2,68 & bc & 7,67 & B & 2,99 & ad & 2,57 & & 4,44 & $b$ & 95,56 & $\mathrm{~b}$ \\
\hline SP87-4-26 & 2,73 & bc & 7,63 & B & 3,00 & ad & 2,54 & & 2,22 & $b$ & 97,78 & $\mathrm{~b}$ \\
\hline SP87-4-30 & 2,69 & bc & 7,59 & B & 2,94 & ad & 2,58 & $\mathrm{~b}$ & 5,55 & $b$ & 94,45 & $b$ \\
\hline SP87-7-9 & 2,84 & bc & 7,75 & B & 3,08 & & 2,52 & & 17,78 & $b$ & 82,22 & $\mathrm{~b}$ \\
\hline SP87-7-19 & 2,77 & bc & 7,71 & B & 3,04 & & 2,54 & & 13,33 & $\mathrm{~b}$ & 86,67 & $\mathrm{~b}$ \\
\hline SP87-7-20 & 2,80 & bc & 7,82 & B & 3,04 & & 2,57 & & 10,00 & $b$ & 90,00 & $\mathrm{~b}$ \\
\hline SP87-7-23 & 2,70 & bc & 7,80 & B & 3,00 & ad & 2,60 & $\mathrm{~b}$ & 12,22 & $\mathrm{~b}$ & 87,78 & $b$ \\
\hline SP87-7-27 & 2,87 & bc & 7,86 & B & 3,06 & & 2,57 & & 8,89 & $\mathrm{~b}$ & 91,11 & $\mathrm{~b}$ \\
\hline SP87-7-28 & 2,84 & bc & 7,81 & B & 3,01 & ad & 2,60 & $\mathrm{~b}$ & 10,00 & $\mathrm{~b}$ & 90,00 & $\mathrm{~b}$ \\
\hline SP87-25-1 & 2,86 & bc & 7,97 & B & 3,04 & & 2,63 & $\mathrm{~b}$ & 6,67 & $b$ & 93,33 & $b$ \\
\hline SP87-25-3 & 2,78 & bc & 7,95 & B & 3,01 & ad & 2,64 & $\mathrm{~b}$ & 6,67 & $\mathrm{~b}$ & 93,33 & $\mathrm{~b}$ \\
\hline SP87-25-5 & 2,70 & bc & 7,74 & B & 2,94 & ad & 2,64 & $\mathrm{~b}$ & 1,11 & $\mathrm{~b}$ & 98,89 & $\mathrm{~b}$ \\
\hline SP87-25-14 & 2,77 & bc & 7,86 & B & 3,00 & ad & 2,62 & $\mathrm{~b}$ & 8,89 & $\mathrm{~b}$ & 91,11 & $b$ \\
\hline SP87-25-23 & 2,84 & bc & 7,93 & B & 3,05 & & 2,60 & $\mathrm{~b}$ & 7,78 & $\mathrm{~b}$ & 92,22 & $\mathrm{~b}$ \\
\hline SP87-25-29 & 2,88 & bc & 8,05 & B & 3,01 & ad & 2,68 & abd & 10,00 & $\mathrm{~b}$ & 90,00 & $b$ \\
\hline SP87-32-3 & 2,76 & bc & 7,71 & B & 3,08 & & 2,50 & & 8,89 & $\mathrm{~b}$ & 91,11 & $\mathrm{~b}$ \\
\hline SP87-32-5 & 2,79 & bc & 7,81 & B & 3,09 & & 2,53 & & 13,33 & $\mathrm{~b}$ & 86,67 & $\mathrm{~b}$ \\
\hline SP87-32-12 & 2,87 & bc & 7,85 & B & 3,13 & & 2,50 & & 24,44 & $\mathrm{~b}$ & 75,56 & $\mathrm{~b}$ \\
\hline SP87-32-14 & 2,78 & bc & 7,98 & B & 3,10 & & 2,58 & $\mathrm{~b}$ & 8,89 & $\mathrm{~b}$ & 91,11 & $\mathrm{~b}$ \\
\hline SP87-32-29 & 2,70 & bc & 7,74 & B & 3,12 & & 2,48 & & 4,44 & $\mathrm{~b}$ & 95,56 & $\mathrm{~b}$ \\
\hline SP87-32-30 & 2,55 & $\mathrm{~b}$ & 7,56 & B & 3,04 & & 2,48 & & 12,22 & $\mathrm{~b}$ & 87,78 & $\mathrm{~b}$ \\
\hline PP48-5-1 & 2,68 & bc & 8,79 & abd & 2,89 & ad & 3,03 & abd & 5,55 & $\mathrm{~b}$ & 94,45 & $\mathrm{~b}$ \\
\hline PP48-5-2 & 2,72 & bc & 8,73 & abd & 2,87 & ad & 3,04 & abd & 3,33 & $\mathrm{~b}$ & 96,67 & $\mathrm{~b}$ \\
\hline PP48-5-6 & 2,76 & bc & 8,69 & abd & 2,88 & ad & 3,02 & abd & 2,22 & $\mathrm{~b}$ & 97,78 & $\mathrm{~b}$ \\
\hline PP48-5-16 & 2,68 & bc & 8,72 & abd & 2,86 & ad & 3,05 & abd & 2,22 & $\mathrm{~b}$ & 97,78 & $\mathrm{~b}$ \\
\hline PP48-5-20 & 2,72 & bc & 8,84 & abd & 2,88 & ad & 3,06 & abd & 1,11 & $\mathrm{~b}$ & 98,89 & $\mathrm{~b}$ \\
\hline PP48-5-29 & 2,58 & $\mathrm{~b}$ & 8,70 & abd & 2,83 & ad & 3,08 & abd & 0,00 & $\mathrm{~b}$ & 100,00 & $\mathrm{~b}$ \\
\hline Sintanur (a) & 2,82 & & 8,09 & & 3,12 & & 2,59 & & 5,55 & & 94,45 & \\
\hline PTB33 (b) & 2,29 & & 6,92 & & 2,77 & & 2,50 & & 73,34 & & 26,66 & \\
\hline Ciherang (c) & 2,55 & & 8,74 & & 2,50 & & 3,50 & & 1,11 & & 98,89 & \\
\hline Pandanwangi (d) & 2,82 & & 8,08 & & 3,14 & & 2,57 & & 2,22 & & 97,78 & \\
\hline LSI taraf 5\% & 0,09 & & 0,12 & & 0,10 & & 0,07 & & 9,32 & & 9,32 & \\
\hline
\end{tabular}

Keterangan: Angka yang diikuti dengan tanda $(\mathrm{a} / \mathrm{b} / \mathrm{c} / \mathrm{d})$ menunjukkan nilai yang lebih baik dibandingkan genotipe pembanding/cek dengan tanda yang sama berdasarkan uji LSI taraf 5\%. Kode-kode untuk karakter yang diamati adalah: bobot 100 butir (B), panjang gabah (P), lebar gabah (L), rasio P/L (PL Ratio), pengapuran (PK), dan kebeningan (K).

Pada karakter panjang gabah (Tabel 1) dapat diketahui bahwa panjang seluruh genotipe hasil persilangan antara varietas Sintanur X PTB33 (SP) hanya memiliki panjang yang lebih baik dari salah satu tetuanya (PTB33), sedangkan genotipe-genotipe hasil persilangan varietas Pandanwangi X PTB33 (PP) memiliki panjang yang lebih baik dari 3 varietas pembanding (varietas Sintanur, PTB33, dan 
Pandanwangi), tetapi, tidak lebih baik dari varietas Ciherang. Genotipe yang memiliki panjang gabah terpendek yaitu genotipe SP87-32-30, dengan nilai $7,56 \mathrm{~mm}$, sedangkan genotipe yang memiliki ukuran gabah yang terpanjang yaitu terdapat pada genotipe PP48-5-20 dengan nilai 8,84 $\mathrm{mm}$.

Pada karakter lebar gabah diharapkan genotipe-genotipe yang diuji memiliki lebar gabah yang kecil. Pada Tabel 1 dapat diketahui bahwa 17 genotipe uji (SP87-4-13, SP87-4-21, SP87-4-24, SP87-4-26, SP87-4-30, SP87-7-23, SP87-7-28, SP8725-3, SP87-25-5, SP87-25-14, SP87-25-29, PP48-5-1, PP48-5-2, PP48-5-6, PP48-5-16, PP48-5-20, dan PP48-5-29) memiliki lebar gabah yang lebih kecil dari dua varietas pembandingnya yaitu Sintanur dan Pandanwangi, tetapi tidak lebih kecil dari lebar gabah pada genotipe PTB33 dan Ciherang. Selain itu,13 genotipe uji (SP87-4-8, SP87-7-9, SP87-7-19, SP87-720, SP87-7-27, SP87-25-1, SP87-25-23, SP87-32-3, SP87-32-5, SP87-32-12, SP87-32-14, SP87-32-29, dan SP87-32-30) lainnya memiliki lebar gabah yang tidak lebih kecil dari lebar seluruh varietas pembandingnya.

Lebar gabah yang lebih kecil saat ini banyak menjadi tujuan dari upaya pemuliaan pada tanaman padi. Hal ini sejalan dengan pernyataan Hossain et al. (2009) yang menyatakan bahwa peningkatan panjang pada biji lebih diinginkan daripada peningkatan lebar karena akan berpengaruh pada bentuk butiran yang dihasilkan. Jika lebar gabah lebih kecil maka butiran yang dihasilkan akan memiliki bentuk yang ramping. Butir beras yang panjang dan ramping umumnya disukai oleh konsumen di Cina Selatan, AS, dan negara-negara di Asia Tenggara dan Selatan, sedangkan konsumen di Jepang, Korea, dan Cina Utara lebih memilih butir beras yang pendek dan bundar (Unnevehr et al., 1992; Juliano \& Villareal, 1993).

Nilai rasio panjang per lebar $(\mathrm{P} / \mathrm{L})$ gabah dapat dilihat pada Tabel 1. Pada Tabel 1 dapat diketahui bahwa tujuh genotipe uji (SP87-25-29, PP48-5-1, PP48-5-2, PP48-5-6, PP48-5-16, PP48-520, dan PP48-5-29) memiliki rasio P/L yang lebih baik dari seluruh tetuanya (Sintanur, PTB33, dan Pandanwangi), tetapi tidak lebih baik dari varietas Ciherang sebagai varietas pembanding lainnya. Sepuluh genotipe uji (SP87-4-21, SP87-4-30, SP87-723, SP87-7-28, SP87-25-1, SP87-25-3, SP87-25-5, SP87-25-14, SP87-25-23, dan SP87-32-14) memiliki nilai rasio $\mathrm{P} / \mathrm{L}$ yang lebih baik dari satu tetuanya yaitu PTB33. Sedangkan 13 genotipe lainnya (SP87-4-8, SP87-4-13, SP87-4-24, SP87-4-26, SP87-7-9, SP87-719, SP87-7-20, SP87-7-27, SP87-32-3, SP87-32-5,
SP87-32-12, SP87-32-29, dan SP87-32-30) tidak lebih baik dari seluruh varietas pembandingnya.

Rasio P/L gabah penting untuk diketahui karena akan menentukan kategori bentuk dari gabah yang diamati. Hasil pengamatan terhadap bentuk gabah menunjukkan bahwa genotipe-genotipe hasil persilangan antara padi varietas Sintanur X PTB33 (SP) memiliki bentuk yang seragam yaitu berbentuk sedang karena memiliki nilai rasio P/L 2,1-3,0 seperti tetuanya (Tabel 1). Sedangkan pada genotipegenotipe hasil persilangan dari padi varietas Pandanwangi X PTB33 (PP) seluruhnya memiliki bentuk gabah yang ramping karena memiliki nilai rasio $\mathrm{P} / \mathrm{L}$ lebih dari 3,0.

Menurut Huang et al. (2013) bentuk butiran adalah karakter penting yang memiliki dampak besar terhadap harga beras di pasar. Di Indonesia sendiri, beras yang memiliki bentuk ramping dan panjang lebih disukai dari beras yang berbentuk lebih pendek. Oleh sebab itu, beras dengan bentuk ramping dan panjang merupakan salah satu tujuan dari pemuliaan.

Bentuk gabah termasuk panjang dan lebar gabah merupakan karakter kuantitatif yang dikendalikan oleh banyak gen dengan efek aditif dan dominan (Shi \& Shen, 1996). Welsh (1981) menyatakan bahwa aksi gen aditif dapat menyebabkan segregasi transgresif, yaitu segregasi yang menyebabkan keturunannya lebih baik atau buruk dari kedua tetuanya. Oleh sebab itu, bentuk gabah yang ramping dan lebih baik dari seluruh tetuanya pada genotipe-genotipe hasil persilangan varietas Pandanwangi X PTB33 (PP) diduga terjadi karena efek gen aditif tersebut.

Pada karakter pengapuran diharapkan genotipe-genotipe uji memiliki persen pengapuran yang kecil. Pada Tabel 1 dapat dilihat bahwa pengapuran pada seluruh genotipe uji hanya lebih kecil dari tetua PTB33 saja dan tidak lebih baik dari varietas Sintanur, Ciherang, serta Pandanwangi. Genotipe PP48-5-29 merupakan genotipe dengan pengapuran terendah dengan persentase pengapuran sebesar 0\%, sedangkan genotipe SP87-32-12 memiliki persentase pengapuran tertinggi yaitu mencapai $24,44 \%$. Pengapuran pada beras akan mempengaruhi kualitas penampilan yang akan berdampak pada harga di pasar. Menurut Badan Standarisasi Nasional (BSN) (2015) bahwa persentase butir mengapur pada beras yang dapat digolongkan dalam beras kategori premium sampai medium 3 berada pada kisaran 0$5 \%$, sehingga jika persen pengapurannya lebih dari ketentuan tersebut beras akan sulit diterima oleh masyarakat. 
Pengapuran pada seluruh genotipe yang diuji cenderung seragam karena pengapuran merupakan karakter yang dikendalikan oleh satu gen inti (monogenic) (Zhou et al., 2009). Selain disebabkan oleh genetik, terbentuknya pengapuran pada butiran dapat disebabkan oleh faktor lingkungan, baik biotik maupun abiotik. Faktor-faktor tersebut yaitu, umur panen, serangan penyakit, serta pengisian dan pematangan butir yang terlalu cepat akibat suhu udara yang tinggi (Santika \& Aliawati, 2007).

Kebeningan sangat dipengaruhi oleh pengapuran. Semakin tinggi pengapuran maka tingkat kebeningan butiran akan semakin rendah. Pada karakter kebeningan dari tiga puluh genotipe yang diuji dapat diketahui bahwa seluruh genotipe memiliki tingkat kebeningan yang lebih baik dari tetua PTB33 saja, dan tidak lebih baik dari tiga varietas pembanding (Sintanur, Ciherang, dan Pandanwangi) lainnya. Persentase kebeningan tertinggi terdapat pada genotipe PP48-5-29 yaitu sebesar $100 \%$, sedangkan persentase kebeningan terendah terdapat pada genotipe SP87-32-12 yaitu sebesar $75,56 \%$.

\section{SIMPULAN}

Seluruh genotipe hasil persilangan yang diuji memiliki penampilan butiran yang baik, yaitu tingkat pengapuran yang termasuk ke dalam skala tidak ada. Selain itu, berdasarkan uji LSI seluruh genotipe hasil persilangan varietas Pandanwangi X PTB33 (PP) dan SP87-25-29 memiliki mutu fisik bulir yang lebih baik daripada tetuanya pada karakter bobot 100 butir, panjang gabah, lebar gabah, dan rasio $\mathrm{P} / \mathrm{L}$.

\section{UCAPAN TERIMA KASIH}

Terima kasih disampaikan kepada Direktorat Penelitian dan Pengabdian pada Masyarakat, Kementerian Riset, Teknologi dan Pendidikan Tinggi yang telah membiayai riset ini melalui skema Penelitian Unggulan Perguruan Tinggi 2018.

\section{DAFTAR PUSTAKA}

Badan Standarisasi Nasional. 2015. Beras. (SNI 61282015). BSN. Jakarta.

Bhattacharya, KR. 2005. The chemical basis rice enduse quality. In: Toriyama, K, KL Heong, B Hardy (eds) Rice is life: scientific perspectives for the 21st century. Proceedings of the World Rice Research Conference held in Tsukuba, Japan, 4-7 November 2005 pp. 246-248.
Bhogadhi, SC, JS Bentur, CV Durga-Rani, G Thappeta, KN Yamini, NAP Kumar, M Jamaloddin, G Swathi, VJ Lakshmi, KV Bhanu, and PV Satynarayana. 2015. Screening of rice genotypes for resistance to brown plant hopper biotype 4 and detection of $\mathrm{BPH}$ resistance genes. International Journal of Life Science. Biotechechnology \&. Pharma Research. 4(2): 90-95.

Castañeda-Ovando, A, ML Pacheco-Hernández, ME Páez-Hernández, JA Rodríguez, and CA Galán-Vidal. 2009. Chemical studies of anthocyanins: a review. Food Chemistry. 113(4): 859-871.

Chaudhary, RC. 2003. Speciality rice of the world: effect of WTO and IPR on it's production trend and marketing. Journal Food, Agriculture \& Environment. 1(2): 34-41.

del Rosario, AR, VP Briones, AJ Vidal, and BO Juliano. 1968. Composition and endosperm structure of developing and mature rice kernel. Cereal Chemistry. 45: 225-235.

Dwiatmini, K, and H Afza. 2018. Karakterisasi kadar antosianin varietas lokal padi warna sebagai SDG pangan fungsional. Buletin Plasma Nutfah. 24(2): 125-134.

Gao, Y, C Liu, Y Li, A Zhang, G Dong, L Xie, B Zhang, B Ruan, K Hong, D Xue, D Zeng, L Guo, Q Qian, and Z Gao. 2016. QTL analysis for chalkiness of rice and fine mapping of a candidate gene for $q$ ACE9. Rice. 9(41): 1-10.

Girma, BT, H Mohammed, and K Abegaz. 2016. Physical characteristics and nutritional quality of salt tolerant rice genotypes. J. Cereals Oilseeds. 7(2): 7-13.

Hairmansis, A, H Aswidinnoor, Supartopo, WB Suwarno, B Suprihatno, dan Suwarno. 2013. Potensi hasil dan mutu beras sepuluh galur harapan padi untuk lahan rawa pasang surut. Jurnal Agronomi Indonesia. 41(1): 1-8.

Hossain, MS, AK Singh, and Fasih-uz-Zaman. 2009. Cooking and eating characteristics of some newly identified inter sub-specific (indica/japonica) rice hybrids. Science Asia. 35: 320-325.

Huang, R, L Jiang, J Zheng, T Wang, H Wang, Y Huang, and Z. Hong. 2013. Genetic bases of rice grain shape: so many genes, so little known. Trends in Plant Science. 18(4): 218226.

International Rice Research Institute. 2002. Standard Evaluation System for Rice. Philippines: IRRI. Tersedia 
http://www.knowledgebank.irri.org/extensio $\mathrm{n} /$ print-versionses.html (diakses pada tanggal 12 November 2018).

Juliano, BO, and CP Villareal. 1993. Grain Quality Evaluation of World Rice. International Rice Research Institute. Manila, Philippines.

Lestari, AP, B Abdullah, A Junaedi, dan H. Aswidinnoor. 2011. Performance of grain quality and aroma of aromatic new plant type promising rice line. Indonesian Journal of Agricultural Science. 12(2): 84-93.

Petersen, R. 1994. Agricultural Field Experiments Design and Analysis (M. D. Inc., editor). New York, USA.

Richards, RA. 2000. Selectable traits to increase crop photosynthesis and yield of grain crops. Journal of Experimental Botany. 51(1): 447458.

Santika, A, dan G Aliawati. 2007. Teknik pengujian tampilan beras untuk padi sawah, padi gogo, dan padi pasang surut. Buletin Teknik Pertanian. 12(1): 19-23.

Shi, CH, dan ZT Shen. 1996 Additive and dominance correlation analysis of grain shape and yield traits in indica rice. Acta Agron. Sin. 22(1): 3642.

Slafer, GA. 1994. Genetic Improvements of Field Crops: Current Status and Development. Marcel Dekker Inc. New York, USA.

Suryanugraha, WA, Supriyatna, dan Kristamtini. 2017. Keragaan sepuluh kultivar padi lokal (Oryza sativa L.) Daerah Istimewa Yogyakarta. Vegetalika. 6(4): 55-70.
Syahri, dan RU Somantri. 2016. Penggunaan varietas unggul tahan hama dan penyakit mendukung peningkatan produksi padi nasional. Jurnal Litbang Pertanian. 35(1): 2536.

Tan, YF, YZ Xing, JX Li, SB Yu, CG Xu, and Q Zang. 2000. Genetic bases of appearance quality of rice grains in Shanyou 63, an elite rice hybrid. Theoretical and Applied Genetic. 101: 823829.

Thi-Lang, N, PHT Giang, PT Thu-Ha, TB Toan, TA Phuong, dan B Chi-Buu. 2017. Identifying the grain chalkiness gene using molecular marker techniques in rice (Oryza sativa L.). International Letters of Natural Sciences. 63: 18-26.

Toquero, ZF. 1991. Consumer demand for rice grain quality in rice grain marketing and quality issues. Selected paper from The International Rice Reserach Conference, 27-31 August 1990, Seoul, Korea. IRRI. 1991: 37-46.

Unnevehr, L, B Duff and BO Juliano. 1992. Consumer Demand for Rice Grain Quality. International Rice Research Institute, Manila, Philippines.

Welsh, JR. 1981. Fundamentals of Plant Genetics and Breeding. John Wiley and Sons Inc. New York, USA.

Zhou, LJ, LM Chen, L Jiang, WW Zhang, LL Liu, X Liu, ZG Zhao, SJ Liu, LJ Zhang, JK Wang and JM Wan. 2009. Fine mapping of the grain chalkiness QTL qPGWC-7 in rice (Oryza sativa L.). Theoretical and Applied Genetic. 118(3): 581-590. 